Original Research Paper

\title{
Leaves Calorific Values of Selected Species in Burnt Tropical Peat Swamp Forest in Selangor, Malaysia
}

\author{
${ }^{1}$ Gerald Ulok, ${ }^{2}$ Ahmad Ainuddin Nuruddin, ${ }^{3}$ Rusea Go and ${ }^{2}$ Paridah Md Tahir \\ ${ }^{1}$ Faculty of Forestry, Universiti Putra Malaysia, Selangor, Malaysia \\ ${ }^{2}$ Institute of Tropical Forestry and Forest Product, Universiti Putra Malaysia, Selangor, Malaysia \\ ${ }^{3}$ Faculty of Science, Universiti Putra Malaysia, Selangor, Malaysia
}

Article history

Received: 20-05-2015

Revised: 04-03-2016

Accepted: 05-03-2016

Corresponding Author: Ahmad Ainuddin Nuruddin Institute of Tropical Forestry and Forest Product, Universiti Putra Malaysia, Selangor, Malaysia Email: ainuddin@upm.edu.my

\begin{abstract}
Forest fire in Malaysia's peat swamp forest is a major concern since it is contributing to the country's haze episode. Forest fire in peat areas is difficult to be extinguished and may occur for days. Understanding fuel characteristics is the key to develop effective fuel management in peat swamp forest. The objectives of this study were to evaluate the common species coverage and calorific value of the common plants species in the burnt peat swamp forest. The study was conducted in the rehabilitated areas of Raja Musa Forest Reserved, Selangor, Malaysia. 9 plots were established along canal 6 in Compartment 100 of the Raja Musa Forest Reserved. Plants were surveyed in the 9 plots and based on the survey, 8 species (Imperata cylindrica, Macaranga pruinosa, Nephrolepis biserrata, Melastoma malabathricum, Lygodium flexuosum, Uncaria tomentosa, Scleria sumatrensis and Melicope latifolia) most higest coverage found in that area. Scleria sumatrensis had the highest coverage of $40 \%$ followed by Melastoma malabathricum of coverage of $21 \%$. The data suggested that the 8 species covered most of the study area and have the potential to be forest fuel. Uncaria Tomentosa had the highest calorific value with $4832.8 \mathrm{cal} / \mathrm{g}$ while Nephrolepis biserrata had the lowest value of $3825.2 \mathrm{cal} / \mathrm{g}$. The findings concluded that the Sceleria sumatrensis had the highest coverage and calorific values of the selected plants vary with species. These information provide insight on the species common in burnt tropical peat swamp forest and are helpful in formulating forest fire control programme.
\end{abstract}

Keywords: Calorific Value, Peat Swamp Forest, Forest Fuel

\section{Introduction}

Peat swamp forest is one of the important ecosystems in Malaysia and plays significant role in providing a natural habitat for plants and animals. It also serves as carbon storage and functions as a water reservoir. Malaysia's total area of peat swamp forest reserved covers up to 1.07 million hectares (DSM, 2013) which are susceptible to human interference and exploitation. One of the most challenging peat swamp management problem is the occurrences of peat forest fires. Forest fire incidents occur almost every year in Malaysia and the burning scale vary, depending on the area and forest structure.

Malaysia's forest fire is commonly caused by several factors such as drought, land opening and open burning by individuals. The risk of forest fire occurrences increases during the low rainfall season occurring during January to March and June to September (Ainuddin and Ampun, 2008). Land opening with burning method done by small scale farmers also causes fire spread to the adjacent forestland. This burning method is considered the cheapest method (Goldammer, 1993) available to open up land.

Lailan et al. (2004) classified forest fire in peat swamp forest into two types, smoldering and flaming combustion. The smoldering combustion takes place in the subsurface area and burns downward while flaming combustion takes on the surface of the peat. The subsurface fire occurs continuously underground and proceeds further below burning the organic materials which is slowly decomposed by microbes. The fire is hardly detected as the indicator is only visible from the smoke produced. This combustion is usually in peat swamp areas and hardly found in other type of forest. However the surface fire is can be seen as the flame is 
visible and easier to cater compared to smoldering combustion in peat swamp areas.

Forest fires affect ecosystem (Syaufina and Ainuddin, 2011), economic growth (Núñez-Regueira et al., 2002) and public health. The damage of forest caused by fire could affect the forest by changes in the vegetation structure (Ainuddin and Goh, 2010). The haze due to mass destruction of forest by fire in 1997/1998 cost 800 million Malaysian Ringgit to cater the public health, industry's productivity and fire control. The impact of air pollution towards the environment is the increase of carbon dioxide $\left(\mathrm{CO}_{2}\right)$ in the atmosphere (Thonicke et al., 2001) which aids in addition to greenhouse gases.

One of the basic fuel characteristics that influence fire ignition is the calorific value. Calorific value is the energy which is release during combustion (Lailan et al., 2004; Fantu et al., 2007). The calorific value shows the fire intensity of a material once burned. The basic understanding of calorifc value can aid in precautionary measures in forest fire risk management especially in forest prone to fire (Saharjo and Watanabe, 1999). Shrubs have high potential to be ignited due to their high calorific value (Núñez-Regueira et al., 2002) and high coverage of shrubs in an area increases the risk of wildfire occurrences.

In the tropical peat swamp forest, study on the species calorific value and its contribution towards the forest fire is still lacking. Thus the study on calorific value is necessary to provide more information on forest fire in tropical peat swamp forest. Since the species calorific value is regarded as indicator for aboveground fuel efficency in enhancing forest fire, this study aims to determine the calorific value of the commonly found species in the burnt tropical peat swamp forest.

\section{Materials and Methods}

This study was conducted in Raja Musa Forest Reserve located at the north-western of Selangor, Malaysia and it is the largest peat swamp forest in the Selangor. The forest is 73592 hectares and mostly dominated by low to medium density forest stands. Raja Musa Forest Reserve was gazetted in 1990 after heavily harvested for its timber. Timber extraction has stopped in 2007 and serves as production forest, wildlife sanctuary and research.

Raja Musa Forest Reserve experienced forest fire in 2002 and since then occurred annually. These fires occurred in this forest reserve due to the encroachment and agriculture activities occurring in the vicinity of the forest. The small scale farmers are opening up lands using burning for planting bananas, vegetables, tapiocas and many other crops.

The plots were established along the canal 6 which expands approximately 2 kilometers from the entrance to the forest. About 9 plots of $10 \times 10 \mathrm{~m}$ in size were constructed using transect method. Distance between each plot was $250 \mathrm{~m}$. The plots covered the burnt areas up to the forest border. Species inventory was done to identify the major species at the plot and samples from the selected species were collected and weighed. 8 species were identified as the common species available in all of the plots. The leaves of the 8 species were taken for sampling. The samples were gathered in 1 day to avoid any temporal variation (Dimitrakopoulos, 2001).

The fresh weights for all 8 species were weighed onsite before being brought to the laboratory for drying. The collected samples were dried in the industrial oven until constant weight in $60^{\circ} \mathrm{C}$. The drying took 14 days before reaching constant weight. Moisture is calculated as green weight basis.

Determination of calorific value is based on the BSI standard EN 149181 using $0.5 \mathrm{~g}$ oven-dried sample (Chin et al., 2012). The samples were grinded, sieved to $250 \mu \mathrm{m}$ and then divided to 5 replicates each species and tested for the calorific values using LECO Automatic Bomb Calorimeter AC350. The mean calorific values were analyzed with ANOVA to distinguish the difference of calorific value between species.

\section{Results}

Eight main species, Scleria sumatrensis, Imperata cylindrica, Lygodium flexuosum, Melicope latifolia, Macaranga pruinosa, Melastoma malabathricum, Nephrolepis biserrata and Uncaria tomentosa were observed in the study area. Scleria sumatrensis had the highest coverage followed by Melastoma malabathricum, These are fast growing plants and dominating the burnt area (Fig. 1). Other species observed were Dicranopteris linearis, Acacia mangium, Stenochlaena palustris, Rhynchospora corymbosa, Passiflora foetida, Asystacia gangetica, Lantana camara, Mallotus barbatus, Lycopodium cernuum, Rhynchospora fusca. These species however were low in coverage in the study area. Most of the species are shrubs although some are categorized as woody plants and ferns.

Estimated species coverage percentage is shown in Fig. 1. S. sumatrensis ranked first with $40 \%$ coverage in the study plots, followed by $M$. malabathricum, $L$. flexuosum, I. cylindrica, U. tomentosa, M. pruinosa, N. biserrata and lastly, M. latifolia. S. sumatrensis of the Cyperaceae family grows commonly in swampy areas. M. malabathricum ranked second is also a common plant in peat areas and known for its ability in phytoremediation (Watanabe et al., 1998). The species is also adaptable in sparse forest type and high moisture condition. I. cylindrica had the highest moisture content which was $70 \%$ followed by $S$. sumatrensis, $U$. tomentosa, M. pruinosa, $N$. biserrata, $M$. malabathricum, M. latifolia and last was L. flexuosum. 


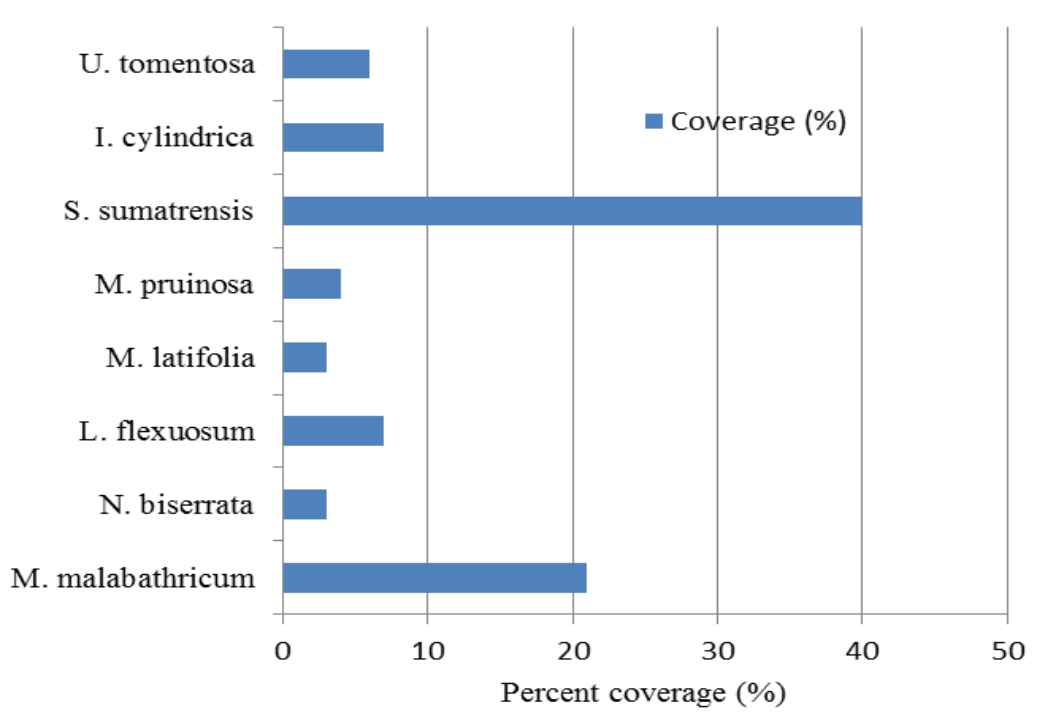

Fig. 1. Percentage coverage of plants at Hutan Simpan Raja Musa

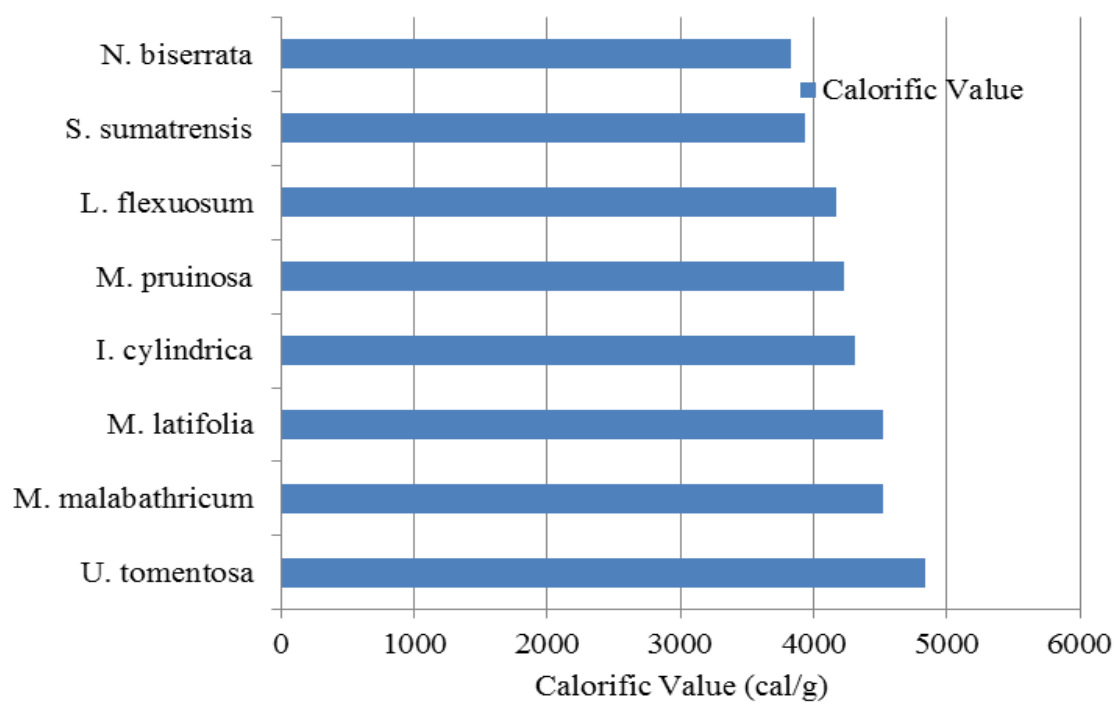

Fig. 2. Mean leaves calorific values of selected species in Raja Muda Musa Forest Reserved

Table 1. Percentage of estimated coverage of selected species in Hutan Simpan Raja Musa

\begin{tabular}{ll}
\hline Species & Moisture content (\%) \\
\hline Melastoma malabathricum & $53.33 \pm 3.01$ \\
Nephrolepis biserrata & $55.00 \pm 3.35$ \\
Lygodium flexuosum & $43.48 \pm 2.59$ \\
Melicope latifolia & $47.83 \pm 6.87$ \\
Macaranga pruinosa & $62.07 \pm 3.95$ \\
Scleria sumatrensis & $65.00 \pm 0.60$ \\
Imperata cylindrica & $70.00 \pm 4.77$ \\
Uncaria tomentosa & $62.07 \pm 3.00$ \\
\hline
\end{tabular}

Table 2 shows the mean calorific value based on 5 replicates. The highest calorific value was $U$. tomentosa with $4832.80 \mathrm{cal} / \mathrm{g}$ and the lowest was $N$. biserrata with $3825.20 \mathrm{cal} / \mathrm{g}$. M. latifolia was second highest followed by I. cylindrical (Fig. 2).
Table 2. Mean and standard deviation of leaves calorific values of selected species in Raja Muda Musa Forest Reserved

\begin{tabular}{ll}
\hline Species & Calorific value $(\mathrm{cal} / \mathrm{g})$ \\
\hline Uncaria tomentosa & $4832.8 \pm 108.66^{\mathrm{c}, \mathrm{d}, \mathrm{e}, \mathrm{g}, \mathrm{h}}$ \\
Melicope latifolia & $4524.5 \pm 214.02^{\mathrm{f}, \mathrm{g}, \mathrm{h}}$ \\
Imperata cylindrica & $4310.9 \pm 482.22^{\mathrm{a}, \mathrm{g}, \mathrm{h}}$ \\
Macaranga pruinosa & $4232.0 \pm 90.43^{\mathrm{a}}$ \\
Lygodium flexuosum & $4163.2 \pm 98.79^{\mathrm{a}}$ \\
Scleria sumatrensis & $3940.2 \pm 54.73^{\mathrm{a}, \mathrm{b}}$ \\
Melastoma malabathricum & $3894.4 \pm 31.50^{\mathrm{a}, \mathrm{b}, \mathrm{c}}$ \\
Nephrolepis biserrata & $3825.2 \pm 85.72^{\mathrm{a}, \mathrm{b}, \mathrm{c}}$ \\
\hline
\end{tabular}

\section{Discussion}

I. cylindrica had the highest moisture content while L. flexuosum had the lowest moisture content (Table 1). This variations are due to their physiology process and 
leaf morphology. The results showed that moisture contents varied with species. Each species has its own physiological process of maintaining the moisture of the leaves. It also depends on the stages of leaves growth. Younger leaves will generally tend to have higher moisture compared to older and matured leaves. Moisture content is important in combustion process since it slows the time to ignition ( $\mathrm{Hu}$ and $\mathrm{Ju}, 2008)$. The lower the moisture content, the higher the combustion risk.

Calorific value is the heat release during exothermic process which combustion process is associated with the properties of the material (Liu et al., 2013) without any influence of moisture content and external parameters. Other than that, the inorganic composition (Broido and Nelson, 1964) of the species also can be a contribution factor in evaluation of fuel potential. Saharjo and Watanabe (1999) conducted a study on evaluating species flammability based on silica-free ash content that could influence the energy during combustion. Mutch (1970) also stated that the ash content may inhibit the combustion in pyrolysis. Most of the calorific values from the leaves of the selected plants in this study have similar calorific values when compared to values of selected dipterocarp species studied by (Musa and Nuruddin, 2015). However, calorific value of $U$ tomentosa was highest when compared to the selected dipterocarp species.

S. sumatrensis has the highest coverage percentage but low in calorific value and $U$. tomentosa, has a high calorific value but low in coverage. $U$. tomentosa contains a high percentage of tannins (Heitzman et al., 2005) where it influences the high calorific value and energy release during combustion. Liu et al. (2013) tested 26 fresh leaves on their combustibility found that species with longer ignition delay time is a slow combustible species with a high smoke production and lower heat release.

This information on plant coverage, moisture and calorific values of the selected species in the burnt tropical peat swamp forest can help in further understanding the aboveground fuel dynamics. This information can also be used in fuel modeling and forest fire management.

\section{Conclusion}

Calorific value of the species was used to indicate the forest fuel potential. Other variables such as moisture content and species coverage are also considered in acknowledging the influence towards the forest flammability. The 8 species were examined on their calorific value on dry basis. The highest fuel potential is $U$. tomentosa, followed by M. latifolia, I. cylindrica, $M$. pruinosa, L. flexuosum, S. sumatrensis. $M$. malabathricum and lastly $N$. biserrata in the rehabilitated peat swamp forest.

\section{Acknowledgement}

We would like to address our gratitude to the Faculty of Forestry and Institute of Tropical Forestry and Forest Product (INTROP), Universiti Putra Malaysia for providing the facilities and Ministry of Education grant to fund this research and Forestry Department of Peninsular Malaysia for allowing us to conduct this research in Raja Musa Forest Reserve.

\section{Funding Information}

This research is funded by Ministry of Higher Education, (FRGS: 5524320) grant.

\section{Author's Contributions}

This study is a result of the full collaboration of all the authors.

Gerald Ulok: Responsible for planning, data collection, analysis and interpretation of data. Write and review manuscript.

Ahmad Ainuddin Nuruddin: Conception and design, analysis and interpretation of data. Write and review manuscript.

Rusea Go: Planning and design. Interpretation of data. Review manuscript.

Paridah Md Tahir: Planning and design. Interpretation of data. Review manuscript.

\section{Ethics}

The authors declare that this is an original research and do not have any ethical issues or copyrights conflict.

\section{References}

Ainuddin, N.A. and J. Ampun, 2008. Temporal Analysis of the keetch-byram drought index in Malaysia: Implications for forest fire management. Applied Sci., 8: 3991-3994. DOI: 10.3923/jas.2008.3991.3994

Ainuddin, N.A. and K. Goh, 2010. Effect of forest fire on stand structure in Raja Musa peat swamp forest reserve, Selangor, Malaysia. J. Environ. Sci. Technol., 3: 56-62. DOI: 10.3923/jest.2010.56.62

Broido, A. and M.A. Nelson, 1964. Ash content: Its effect on combustion of corn plants. Science, 146: 652-653. DOI: 10.1126/science.146.3644.652

Chin, K.L., P.K. H'ng, E.W. Chin, B.T. Tey and M.J. Chin et al., 2012. Fuel characteristics of solid biofuel derived from oil palm biomass and fast growing timber species in Malaysia. Bioenergy Resources. DOI: 0.1007/s 12155-012-9232-0

Dimitrakopoulos, A.P., 2001. Thermogravimetric analysis of Mediterranean plant species. J. Analytical Applied Pyrolysis, 60: 123-130. DOI: 10.1016/S0165-2370(00)00164-9 
DSM, 2013. Environmental statistics times series Malaysia. Department of Statistics, Malaysia.

Fantu, W., N.A. Ainuddin, A.H. Faizah and A.M. Abdul Rashid, 2007. Fuelwood properties of six tree species grown in Ethiopia. Ethiopian J. Natural Resources, 9: 63-86.

Goldammer, J.G., 1993. Fire Management. In: Tropical Forestry Handbook, Pancel, L. (Ed.), Springer-Verlag, Berlin, ISBN-10: 0387564209, pp: 1221-1267.

Heitzman, M.E., C.C. Neto, E. Winiarz, A.J. Vaisberg and G.B. Hammond, 2005. Ethnobotany, phytochemistry and pharmacology of Uncaria (Rubiaceae). Phytochemistry, 66: 5-29.

DOI: $10.1016 /$ j.phytochem.2004.10.022

$\mathrm{Hu}, \mathrm{H} . \mathrm{Q}$. and L. Ju, 2008. Fire resistance of eight broadleaf woody species in Xiaoxing'an Mountain. Scientia Silvae Sinicae, 44: 90-95.

Lailan, S, A.N. Ainuddin, B. Jamaluddin, F.S. Lai and M.Y. Mohd Rashid, 2004. The effects of climatic variations on peat swamp forest condition and peat combustibility. PhD Thesis, Universiti Putra Malaysia.

Liu, M.H., L.T. Yi, S.Q. Yu, G.M. Zhou and H. Jiang et al., 2013. Combustibility of fresh leaves of 26 forest species in China. J. Tropical Forest Sci., 25: 528-536.

Musa, D.N.S. and A.A. Nuruddin, 2015. Calorific value of leaves of selected dipterocarp trees species in Piah Forest Reserve, Perak. J. Tropical Resources Sustainable Sci., 3: 132-134.
Mutch, R.W., 1970. Wildland fires and ecosystem-a hypothesis. Ecology, 51: 1046-1051.

DOI: $10.2307 / 1933631$

Núñez-Regueira, L., J. Rodriguez-Añón, J. Proupín and A. Vilanova Diz, 2002. Calorimetry as a tool to design campaigns to prevent and fight forest fires originating from shrub species. Thermochimica Acta, 394: 279-289. DOI: $10.1016 / \mathrm{S} 0040-6031(02) 00260-5$

Saharjo, B.H. and H. Watanabe, 1999. The flammability of shrubs and trees in anAcacia mangium plantation based on silica-free ash content. J. Forest Res., 4: 57-59. DOI: $10.1007 / \mathrm{BF} 02760326$

Syaufina, L. and A.N. Ainuddin, 2011. Impacts of fire on SouthEast Asia tropical forests biodiversity: A review. Asian J. Plant Sci., 10: 238-244.

DOI: 10.3923/ajps.2011.238.244

Thonicke, K., S. Venevsky, S. Sitch and W. Cramer, 2001. The role of fire disturbance for global vegetation dynamics: Coupling fire into a dynamic global vegetation model. Global Ecol. Biogeography, 10: 661-677. DOI: 10.1046/j.1466-822X.2001.00175.x

Watanabe, T., M. Osaki, T. Yoshihara and T. Tadano, 1998. Distribution and chemical speciation of aluminium in the $\mathrm{Al}$ accumulator plant, Melastoma malabathricum L. J. Plant Soil, 201: 165-173. DOI: $10.1023 / \mathrm{A}: 1004341415878$ 